\title{
Prospecting the potential of ecosystem restoration: A proposed framework and a case study
}

\author{
Alexandre Marco da Silva*, Ludmila Araujo Bortoleto, Karen Regina Castelli, \\ Rosiane Argenton e Silva, Pablo Bettio Mendes
}

Department of Environmental Engineering, Institute for Science and Technology of Sorocaba, São Paulo State University, 511, Tres de Marco Avenue, Altos da Boa Vista, Sorocaba, SP, 18087-180, Brazil

\section{A R T I C L E I N F O}

\section{Keywords:}

Assisted restoration

Ecological restoration

Environmental degradation

Landscape connectivity

Multi-scale model

Passive restoration

\begin{abstract}
A B S T R A C T
Projects focusing on the restoration of degraded ecosystems have to be financially appealing, spatially multiscaled, and ecologically efficient. Considering such premises, a model was elaborated to assess the locals in relation to the kind of management to be adopted (conservation or restoration) and, for locals indicated for restoration, the kind of restoration to be adopted (assisted or passive). Furthermore, we propose a set of ecologically-based alternatives at medium- and local-scale to assist the restoration of areas considered unsuitable for passive restoration. Such techniques are: install artificial connectors among forest fragments near each other, or, for areas where forest fragments are far each other, install nucleation techniques, revitalization of concrete-lined urban rivers, and the control of erosion and invasive plant species. We tested the potential of our model through a case study carried out in Sorocaba, Sao Paulo State, Brazil. The study area is predominantly occupied by pasture lands, but urbanization also is an important land cover category. There are 661 forest fragments, being 25 of them larger than 50 ha. From the area considered "non-habitat", i.e., modified due to human usage, $35.5 \%$ of the total study area and $45.5 \%$ of the study area classified as non-habitat is suitable for passive restoration, and the rest of the area needs is suitable only for assisted restoration techniques. We verified that the facility and low cost of installation are advantageous features of such techniques and the results obtained by mean of application of the assisted techniques indicate that the alternatives tend to accelerate the process of establishing connectivity of the landscape in locals devoid of connections.
\end{abstract}

\section{Introduction}

Humans are transforming the biosphere in unprecedented ways, and changes in land cover are one of the main pathways of this transformation (McGill et al., 2015). One of the main impacts of this change involves impacts on biodiversity, usually by impoverishing the number of species (Lambin and Geist, 2008). The number of species is usually diminished because of habitat fragmentation and the invasion (or intentional introduction) of exotic species (Tilman et al., 2017).

Hence, we are faced with two alternatives: conserving the remaining natural habitats and restoring the ecosystem functions of those already degraded. Ecosystem functions relate to the structural components of an ecosystem (e.g. soil, water, vegetation, biota, and atmosphere) and how they interact with each other, within ecosystems and across ecosystems (Jax, 2005; Poschlod and Braun-Reichert, 2017), and might be exemplified as soil generation and fertility, regulation of hydrological flow and purification of water, dispersal of seeds and other propagules, manufacture of organic materials from inorganic ones by producers, among others (Marcot and Vander Heyden, 2001; Schulze and Mooney, 2012; Traveset et al., 2013).

Given the urgency with which management problems need to be tackled, habitat managers are frequently unable to wait for rigorous tests of threshold theory to determine whether the systems they are attempting to manage exhibit threshold or hysteresis dynamics (Suding and Hobbs, 2009).

To be attractive and viable in terms of management, ecological restoration projects should be financially appealing, ecologically efficient, multifaceted, and incorporate realistic disturbance frequencies (Whisenant, 1999; Walker et al., 2007). These projects require technical and ecological knowhow to address threats to soil and species loss and to support ecological succession and ecosystem health (Suding and Hobbs, 2009; Murcia et al., 2015).

Ecological restoration can be achieved via two main approaches (Prach and Hobbs, 2008; Speed et al., 2016). The first, called passive

\footnotetext{
* Corresponding author.

E-mail address: amsilva@sorocaba.unesp.br (A.M.d. Silva).
} 
restoration or unassisted natural succession, requires no intervention; it is a low-cost restoration option and may be considered suitable when a degraded system appears to have the capacity to recover unaided (Hobbs and Cramer, 2008). The second, called technical or assisted restoration, is usually considered based on the need to manipulate either physical environmental conditions or biota in order to accelerate the process of restoration and drive the process to the desired goal (Jackson and Hobbs, 2009).

There are several GIS-based models for various types of environmental analyses, including erosion (Beskow et al., 2009), environmental risk (Yin et al., 2014), landscape connectivity (Liu et al., 2014), and restoration measures (Piniewski et al., 2012; Patel et al., 2015). GIS-based models that support the indication of suitable areas for passive or assisted restoration actions also exist (O'Neill et al., 1997; Bortoleto et al., 2016; Vettorazzi and Valente, 2016). The development of a multi-scaled and integrated project, embracing both passive and assisted restoration, might be useful for indicating suitable areas to receive both types of actions for restoration and for identifying the best point or local alternatives to restore ecosystem functions.

Hence, we elaborated a model to assess the locals in relation to the kind of management to be adopted (conservation or restoration) and, for locals indicated for restoration, the kind of restoration (assisted or passive). Furthermore, we propose, conjugated with a study case, a set of suitable ecologically-based alternatives at medium- and local-scale to assist the restoration of areas considered unsuitable for passive restoration.

\section{Materials and methods}

\subsection{Background on the model}

The framework was designed following guidelines from Higgs (1997) and Bergen et al. (2001), aiming to:

- take into account the principle of a top-down model in terms of scale, i.e., starting from a generalized, broad scale and moving towards a local, point scale;

- not be species-specific, but rather to focus on the structure and particularly the functionality of the ecosystems;

- allow for local and adaptive management practices, using the maximum resilience potential of the local area;

- encourage interaction between scientists and stakeholders, while aiming to be socially feasible and acceptable;

- be easily understandable by those without expertise in ecological recovery and restoration;

- be based on scientifically established knowledge and considering financially realistic and attainable alternatives, although the use of local, indigenous knowledge might also be taken into account; and - require material that is easy to obtain in order to begin the analysis (i.e. satellite images) and that can be developed straightforwardly, regardless of the GIS package used.

\subsection{Case study development}

The case study approach allowed us to test the proposed conceptual framework in a real-world situation; it was adopted and is described as follows.

\subsubsection{Local features of the case study area}

The area considered in this study was the Sorocaba municipality, in southeast Brazil, (Fig. 1 - see link to Google Earth), which covers an area of $449.8 \mathrm{~km}^{2}$ (IBGE, 2016). Summers in this region are usually rainy and warm (mean monthly precipitation of $176 \mathrm{~mm}$ and mean monthly temperature of $24.6^{\circ} \mathrm{C}$ ) while winters are usually moderately cold and dry $\left(47.6 \mathrm{~mm}, 19.0^{\circ} \mathrm{C}\right)$. Oxisols and Alfisols are the major soil types; both are typically brown and deep with very low or no stoniness,
Gleysols and Cambisols also occur within the region (Oliveira et al., 1999). The terrain is predominantly gently sloped, and in some areas, it is moderately or even strongly sloped. In geological terms, the bed rocks are generally fine- to medium-grained sandstones (IGSP, 2009).

The study region contains a dense river network, with at least 2332 headwaters and approximately $1199 \mathrm{~km}$ of river channels (Silveira et al., 2009). The area was originally an ecotonal region combining Atlantic Rain Forest and Brazilian Savanna vegetation (Kronka et al., 2005); however, most of the vegetation was removed, especially in the second half of the last century, to establish agricultural land and residential districts.

In 2016, the population of Sorocaba was approximately 650,000 , with over $98 \%$ of its residents living within urban zones (IBGE, 2016). Land cover changes, for human purposes, have been occurring in this area for the past 400 years; in the last three decades in particular, considerable changes have occurred, principally to increase urbanization and expand road networks. Such shifts in landscape patterns have provoked a strong reduction in ecological connectivity at both the local and regional levels (Smith et al., 2014). Currently, hundreds of forest fragments are dispersed throughout the study area (Bortoleto et al., 2016). In the past five years, municipal staff has demonstrated more concern regarding the loss of natural areas and connectivity among the remaining forest fragments, as well as for other environmental problems (for example, pollution of the Sorocaba River, the major river crossing the city). This has generated opportunities for dialog between local universities and municipal staff, with the goal of elaborating and executing projects focusing on environmental conservation and recovery. This interaction has seen the creation of at least two municipal parks, the strengthening of conservation efforts in existing parks, and the restoration of riparian vegetation along several streams within the municipality, among others. In addition, opportunities have arisen for the development of ecological and engineering-related projects at local and regional scales.

\subsubsection{Case study methodology}

We selected a Landsat- 8 image satellite (path/row 220/76, April 9, 2016) and classified it using the supervised maximum likelihood classification method, following the steps described in Bortoleto et al. (2016). In brief, land cover data on 176 georeferenced points were collected through several field visits and were used during the classification. The mapping was validated, with the map reaching an $85 \%$ similarity with field data, as assessed using Cohen's kappa coefficient (Lillesand et al., 2014). The land cover categories used were wood sites, water bodies, pasture land, agricultural fields, bare ground, and urban settlements.

Following the completion of these steps, the land cover map was ready for use in testing the model.

\section{Results}

\subsection{The model}

The model is summarized as a flowchart (Fig. 2) and is described literatim ahead. We assume that users of the model are in possession of a digital, georeferenced land cover map of the region of interest to be studied.

The first step was to categorize the map into areas classified as habitat and non-habitat. This simplification of the analysis process allows the identification of areas with the potential to host natural biodiversity. We proceeded with the steps systematically, as described below.

The steps:

A - Develop the land cover map: The analysis began with the classification of the digital image satellite to generate a land cover map. We understand that different users of the model may create different categories of land cover; regardless of the classes of anthropogenic 


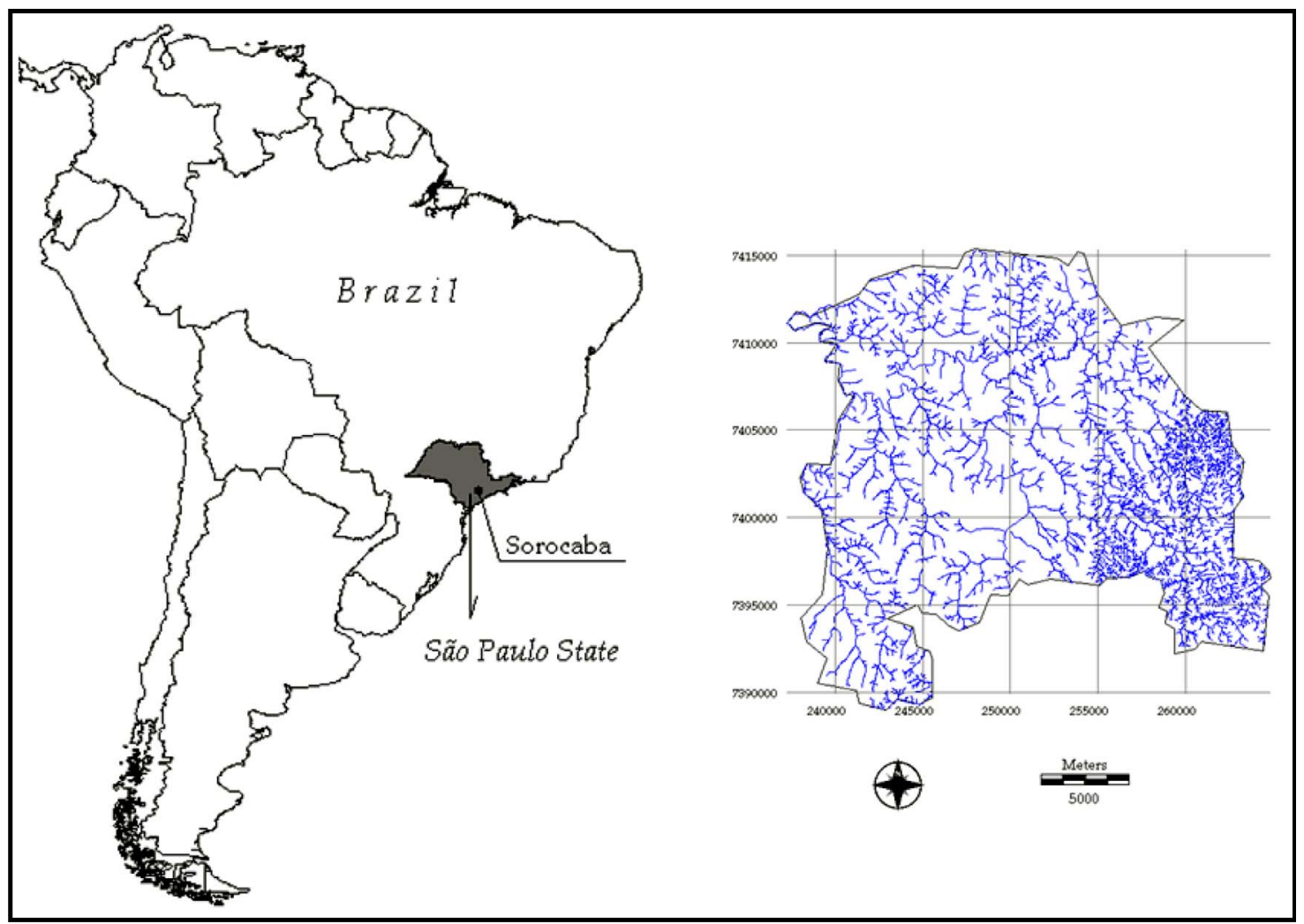

Fig. 1. Left: location of the Brazilian Territory, São Paulo State and Sorocaba Municipality. Right: geopolitical boundaries and river network of Sorocaba (coordinates UTM - 23S).

influence (urban, agriculture, mining, or others), they will be all converted into one single category later on in the process.

However, we also highlight the importance of precisely classifying the classes representing remaining naturally forested areas, as they have important consequential implications, as explained below. After the classification and generation of the land cover map, a bimodal map is generated.

$B$ - Reclassify the land cover map: Land cover classes are categorized into habitat or non-habitat.

B.1 - Habitat: This category includes areas of forest cover, regardless

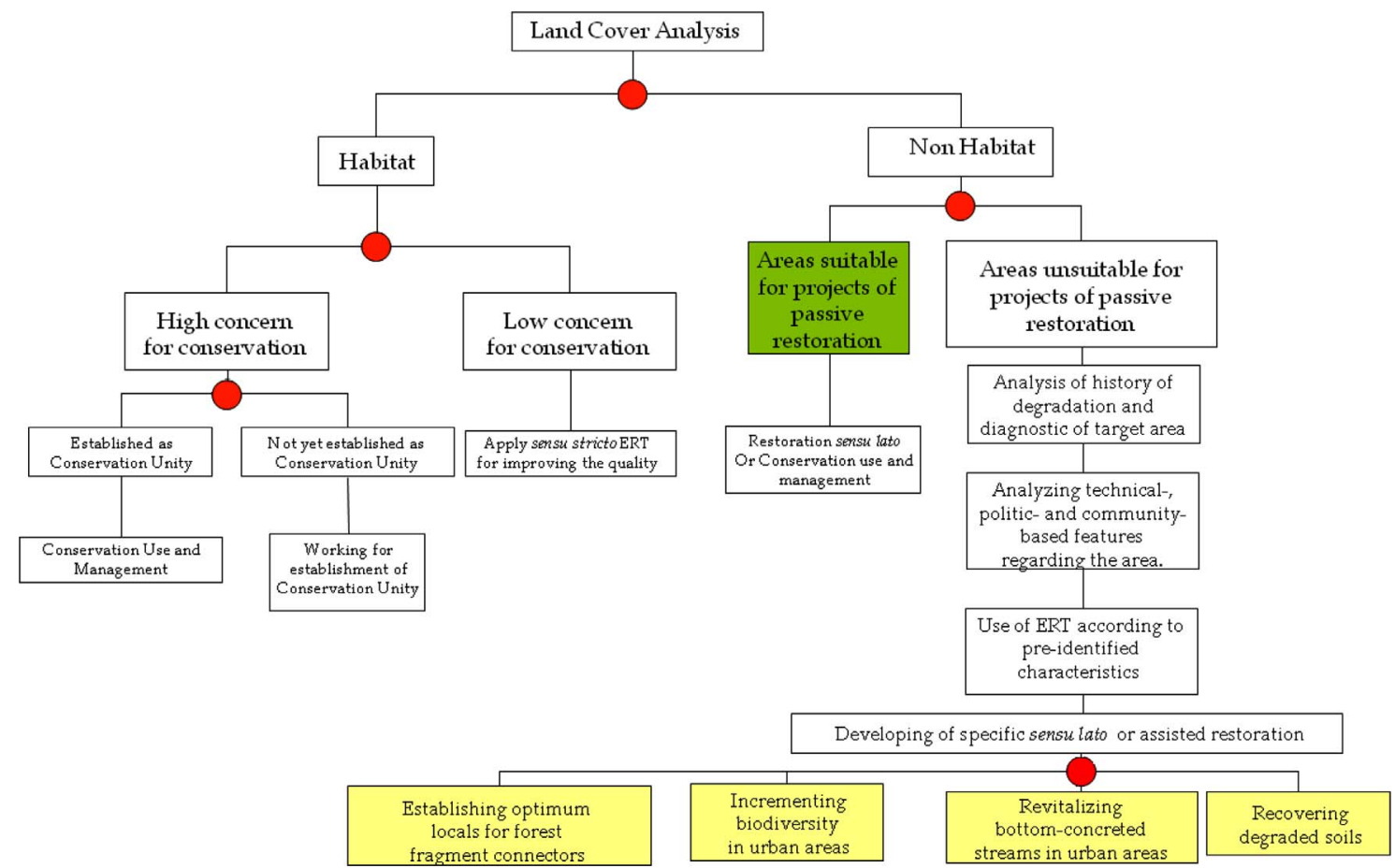

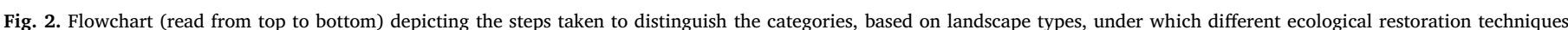

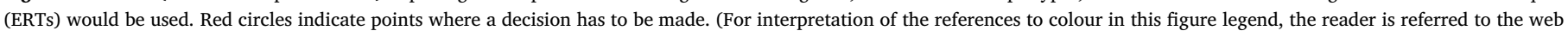
version of this article.) 
of the total area and shape of the forest fragment.

B.2 - Non-habitat: This category includes areas where forest cover no longer occurs (go to step "D").

C - Reclassify the habitat category: For the regions classified as habitat, we assessed the areas according to their conservation priority based on the attribute area of the fragment, taking into account that the area is not the only important aspect here, but is the most important consideration when planning tropical forest reserves (Hill and Curran, 2003). We assumed that each biome needs a minimal area to adequately execute essential ecosystem functions, and the larger the forest fragment is, the better the ecosystem will function and have a higher potential for self-perpetuation. Therefore, to execute the model, the user needs to establish the minimal area of a fragment to be categorized as being of:

C.1 - High value for conservation - they are forest fragments larger than the minimum area established by the user.

C.1.1 - Areas already established as a Unity of Nature Conservation (UNC): areas being used for research and educational proposes; the recipients of conservationist management practices.

C.1.2 - Areas not yet established as UNC: areas where the primary goal is to establish or register a status as a UNC (governmental or nongovernmental), in order that they can also be recipients of conservationist management practices.

C.2 Low value for conservation - they are Forest fragments categorized as being of 'low concern for conservation': areas below the minimal area established by the user. The goal here is to apply sensu stricto ecological restoration techniques (Aronson et al., 1993) and try to conserve them to be used as "stepping stones" for further restoration. Here we consider stepping stone a series of small, non-connected habitats which are used by wildlife to find shelter, food, or to rest.

$D$-Reclassify the non-habitat category: we propose a sub-division into two categories:

D.1 - Areas suitable for ecological restoration projects using passive or non-assisted techniques: For this sub-category, we recommend the mapping of all the non-habitat areas in order to identify their potential for passive restoration. For this step, we suggest the use of the SIR model (suitability index for restoration of a landscape) proposed by Bortoleto et al. (2016) that can be used for any region worldwide, combined with a GIS package, which only requires the application of a digital, georeferenced land cover map. To categorize the areas according to their potential for passive restoration, this model considers two main factors: distance between the forest fragments and the quality of the neighboring fragments. The basic mathematical model is:

$\mathrm{SIR}=\mathrm{Cd} \times(\mathrm{LQ})^{2}$

Where: SIR - suitability index for restoration of a landscape; Cd - classes of distance; LQ - index of local quality. All factors are dimensionless.

Initially, a raster-based map is prepared. This map depicts a continuous gradient of values of distance (maps constituting a single multi directional proximity for each wood site or forest fragment). Hence, a reclassification procedure is conducted in order to generate a new map indicating the classes of distance and the associated quality according to class of distance. This new map was used in the computing of the Cd metric in Eq. (1). In terms of delineating values for the distance classes, the user of the model is free to use values appropriate to the regional con-text and the goals of the project (Bortoleto et al., 2016).

The second variable of the SIR model (LQ) represents the effect of a set of drivers that affect the seed transport, deposition, germination and plant growing, and also seed predation, competition with non-native vegetation, and level of soil fertility or degradation, and reflects how the process of natural regeneration might be favored or hampered in some altered areas. Hence, a numeric value is signed for each land cover class, and this value reflects the quality of the land cover class.

The main recommendation for the areas suitable for passive restoration is eliminating the degradation factor(s) in the area. This could be done by reducing the presence of cattle, controlling fires, limiting erosion, or controlling invasion by exotic species. This potentially means that after the elimination of these factors, ecological succession will follow a trajectory in which the 'new' environment will have characteristics very similar to that of a pristine ecosystem.

D.2 - Areas unsuitable for projects using passive restoration techniques: areas where passive restoration would not be effective require assisted or guided restoration. This implies a necessity to eliminate degrading factor(s) and perform interventions that accelerate restoration. Areas where assisted restoration is necessary will be evaluated for their suitability to receive one of these proposed interventions:

D.2.1 - Establish the optimum locations for forest fragment connectors: Landscape connectors are a type of corridor that can support local wildlife. They are often expensive infrastructure that can cross other structures (most often man-made) that are presently being used (e.g. urban settlements, roads, railway tracks). Our model establishes that the potential places for connectors to be constructed are areas (or points) where fragments occur for the shortest distance between fragments exceeding the minimal size set by the user.

D.2.2 - Establish the ecological connectors: The long distance between the larger fragments might be a significant barrier to constructing connectors, as they will have low ecological efficacy and be financially impractical. Therefore, for these situations, we recommend the consideration of nucleation techniques (Boanares and de Azevedo, 2014; Bechara et al., 2016). The decision regarding the technique is a decision to be made by the user and is dependent primarily on the animal and

Table 1

Examples of nucleation techniques.

Sources: Boanares and de Azevedo (2014), Bechara et al. (2016).

\begin{tabular}{|c|c|c|c|}
\hline Technique & Brief description & Advantages & Disadvantages or limitations \\
\hline $\begin{array}{l}\text { Forest litter and soil } \\
\text { seed bank } \\
\text { transposition }\end{array}$ & $\begin{array}{l}\text { An amount of material (litter and/or soil) from } \\
\text { a forest is transported to the desired area to be } \\
\text { restored. }\end{array}$ & $\begin{array}{l}\text { The material has the potential to contain seeds } \\
\text { of local indigenous species, both anemochoric } \\
\text { and also zoochoric, as well as pioneer, } \\
\text { secondary or climactic plant species. }\end{array}$ & $\begin{array}{l}\text { If not well installed, the material might be taken } \\
\text { away by runoff. }\end{array}$ \\
\hline $\begin{array}{l}\text { Natural or Artificial } \\
\quad \text { Perches }\end{array}$ & $\begin{array}{l}\text { Installing structures (perches) to allow birds or } \\
\text { bats resting and depositing fecal material that } \\
\text { contains some kind of seed. }\end{array}$ & $\begin{array}{l}\text { The seeds might be delivered from distant } \\
\text { places and contribute to local genetic diversity. } \\
\text { The structures are usually easy, quick and } \\
\text { cheap to install. }\end{array}$ & $\begin{array}{l}\text { The expected material to be deposited (seeds) is } \\
\text { exclusively zoochoric. The animals might also bring } \\
\text { exotic species. }\end{array}$ \\
\hline Plantation in islands & $\begin{array}{l}\text { Planting seedlings in small patches whose } \\
\text { distance inter-patches is variable according to } \\
\text { the user. }\end{array}$ & $\begin{array}{l}\text { Good seedling survival, strategy relatively } \\
\text { cheap. }\end{array}$ & $\begin{array}{l}\text { More damage to seedlings, usually lower growth of } \\
\text { the plants. }\end{array}$ \\
\hline $\begin{array}{l}\text { Brushwood } \\
\text { transposition }\end{array}$ & $\begin{array}{l}\text { Transporting brushwood material (stems, } \\
\text { leaves, branches, and roots) to a damaged area } \\
\text { and arranging the material in heterogeneous } \\
\text { patches in the degraded area. }\end{array}$ & $\begin{array}{l}\text { It favors the appearance of soil fauna, might } \\
\text { also contribute to fertilizing the soils and to } \\
\text { control erosion. }\end{array}$ & $\begin{array}{l}\text { Depending of the type of material, a risk of fire } \\
\text { might occur. Depending of the kind of plants used } \\
\text { (if from urban areas, or contaminated), it might } \\
\text { discourage the appearance of animals. }\end{array}$ \\
\hline
\end{tabular}


plant species composition of the areas in question. In Table 1 , we list the main techniques that are commonly used in technical restoration projects, as well as their main advantages and disadvantages.

D.2.3 - Revitalize concrete-lined channels in urban areas: Restoration of riparian vegetation is one of the most common ways to connect forest fragments. Considering the steps of the model already been described, it is evident that at least part of the riparian buffer will be considered for restoration and conservation. However, it should be noted that in urban areas, a significant and increasing amount of river stretches have been losing their vegetation and other ecological advantages, are having their beds concreted, and are currently only serving as storm water drainage. The primary function of concreting is to stabilize riverbank erosion; this kind of structure practically imposes the initial conditions for primary ecological succession on the river. Hence, for stretches under such conditions, a set of assisted restoration techniques is highly necessary.

The types of interventions being considered here are those that aim to improve hydrologic, geomorphic, and ecological processes for a degraded river system, and are replacing lost, damaged, or compromised elements of the natural system in the area (Wohl et al., 2005). By use of the model, we propose restorative actions for these areas, especially for stretches of small streams and creeks. A pre-intervention diagnostic assessment is necessary in order to understand the hydrological, sedimentological, and water quality characteristics of the stretch to be revitalized. Afterwards, if necessary, actions are developed to balance these characteristics. This is followed by actions performed in order to increase or ameliorate the ecological diversity for a range of local fauna and flora, as well as their habitat. It is important to emphasize that such actions have to be developed and implemented while favoring dry season hydro-ecological processes and also ensuring no adverse effects on the river flow during peaks in the rainy season. Attention should be paid to the dynamics of organic matter in the rivers; this water quality attribute is very variable among the regions due to the possibility that untreated sewage might be dumped into water bodies. In such cases, organic matter concentrations would increase because untreated sewage has high potential to "sequestrate" other elements, such as heavy metals (Paul and Meyer, 2001).

D.2.4 - Recover degraded soils: Plant restoration might be positively or negatively influenced by changes in the abiotic environment, such as alterations in soil structure or nutrients compared to pre-disturbance conditions. Processes including as accelerated erosion are very common, and can significantly affect soil degradation. They occur in many regions of the planet, and usually damage and impoverish the soil by creating a favorable environment for invasive plants that are able to colonize the degraded environment. This makes re-colonization of the area by native plants difficult and requires technical and assisted intervention for restoration.

For areas where erosion control actions are necessary, bioengineering solutions can be a viable solution. The environments created to control erosion should also allow for re-colonization by native plant species. The goal of such action is to provide a ground cover that can also control, without chemical pesticides, the propagation of invaders that require conditions such as plenty of light to germinate. This kind of technology is very useful in areas such as roadside slopes, which have a strong potential as corridors or carbon sinks (Silva et al., 2010), as well as in forested lands that have recently been burnt.

\subsection{The case study}

\subsubsection{GIS analysis}

As previously described, the analysis started with the development of a land cover map. The map developed shows a significant occurrence of the "pasture land" land cover category (Fig. 3). This map was the basis for all analyses that followed.

After this step, we classified the areas of habitat (fragments of the remaining native forest) and anthropogenic land cover categories.
There were 661 forest fragments in total, and small fragments predominated (Table 2).

We then classified the fragments larger than 50 ha as being of major concern for conservation. This value was established based on previous studies carried out in this region, which found that fragments larger than 50 ha were the best to conserve indigenous biodiversity; some of them are already considered as Unity of Nature Conservation (Smith and Ribeiro, 2015). There were 25 fragments larger than 50 ha. On the other hand, studies have been carried out to identify the role of fragments smaller than 50 ha as 'stepping stones', and the potential to increase their area after passive restoration of the buffer region of the fragment, and thus being considered as a major concern for conservation.

For the areas classified as being non-habitat, i.e., modified due to human usage, we applied the model named Suitability Index for Restoration (SIR model, Bortoleto et al., 2016) and identified $15,922.9$ ha of the non-habitat area suitable for passive restoration with the cessation of degrading actions. This was equal to $35.5 \%$ of the total study area and $45.5 \%$ of the study area classified as non-habitat. We consider other areas, classified as non-habitat but unsuitable for passive restoration, as being places where major investments in terms of labor, logistics, and money would be necessary. This category represents $64.5 \%$ of the total study area and $54.5 \%$ of the study area classified as non-habitat (Fig. 4).

\subsubsection{Techniques for assisted restoration}

After the classification of areas as suitable or unsuitable for passive restoration, a search was performed to identify suitable locations to construct connectors to link large forest fragments, where the quality of the land cover of the inter-patch region is unsuitable for passive restoration. We established $60 \mathrm{~m}$ as the maximum limiting distance between fragments. This was due to the fact that connectors longer than $60 \mathrm{~m}$ might have exceptionally expensive construction costs while also having only a low potential to be used by local wildlife; the more extensive the corridors are, the less often they are used (Chetkiewicz et al., 2006). Using these criteria, we identified one strategic point at which a connector could be installed to join two large fragments in a financially feasible way (Fig. 4). Design parameters for the connector, including its optimal width (whose value varies according to expert opinion (Hilty et al., 2012)) and what habitat elements it should consist of, is a subject that varies according to characteristics of the local (for example species of plants and animals of local occurrence, relief, and type of human intervention that has become a limiting factor to wildlife movement or migration) (USDT, 2011).

Some places in the study area were classified as being non-habitat areas that required assisted restoration actions, but they were not strategic locations for connectors because the distance between large fragments was longer than $60 \mathrm{~m}$. For these, we assessed nucleation techniques as alternatives that would allow the areas become 'stepping stones' in the future. Due to the ecological peculiarities of the region (i.e., kind of biome and composition of animal and plant species), two techniques were considered: artificial perches and seed transposition in forest litter.

The experiments were conducted at three municipal natural parks in Sorocaba. The perches were constructed with eucalyptus wood and were approximately $2 \mathrm{~m}$ long, with two vertical branches that permitted bats and especially birds to rest on them. Following technical suggestions by ornithologists, three variations of the perches were tested: those painted red (to test the attraction or repulsion due to color), perches camouflaged with climbing plants, and perches neither painted nor camouflaged. Three pairs of each variation were installed in each park. For plots with a seed bank, we collected material from a pristine forest sited approximately $10 \mathrm{~km}$ away from the municipal natural parks, due to the genetic similarities that must occur among the communities.

So far, we have found that the colonization by woody plants has 


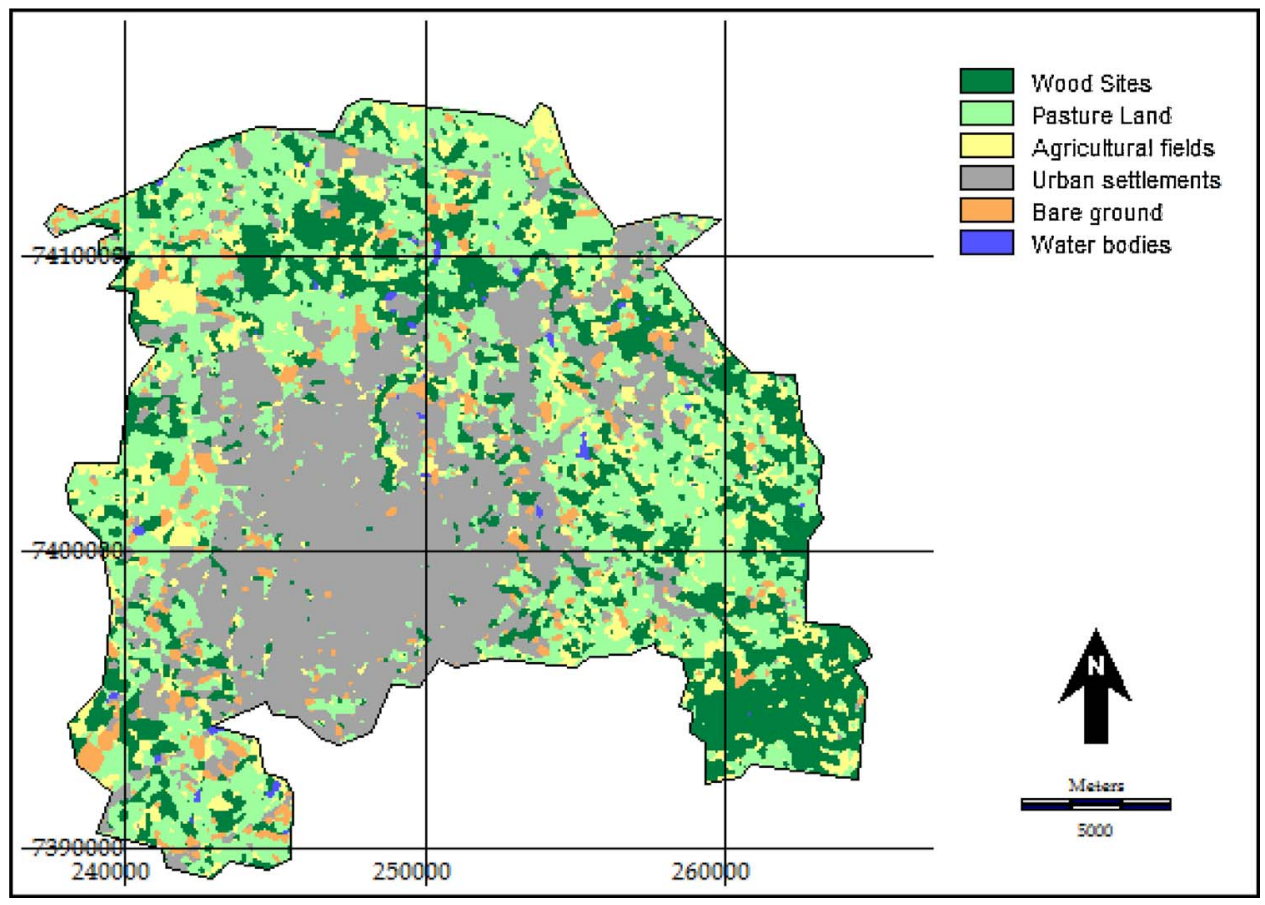

Fig. 3. Land cover map of the study area, generated with a LandSat-8 image from April 9, 2016.

Table 2

Number of forest fragments in the study area in 2016.

\begin{tabular}{lll}
\hline Classes (hectare) & Number of fragments & $\%$ \\
\hline$<1$ & 255 & 38.6 \\
$1.1-10$ & 284 & 43.0 \\
$10-50$ & 97 & 14.7 \\
$50-100$ & 13 & 2.0 \\
$100-250$ & 8 & 1.2 \\
$250-500$ & 2 & 0.3 \\
$500-1000$ & 1 & 0.2 \\
$>1000$ & 1 & 0.2 \\
total fragments & 661 & 100 \\
\hline
\end{tabular}

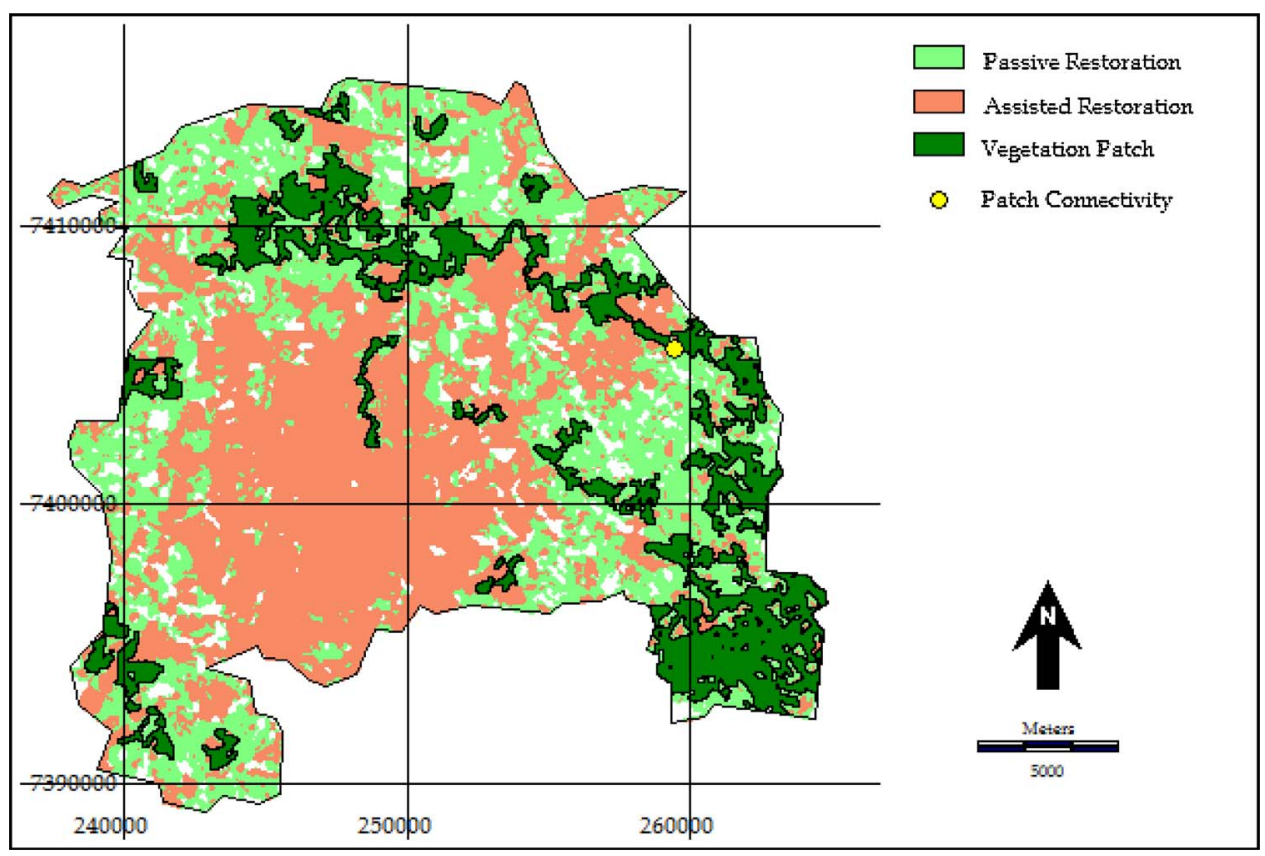

been occurring more successfully in plots with seed transposition from forest litter, possibly due to the reason that seed transposition carried seeds of pioneer, photoblastic species (plants whose germination is stimulated by light). The different methods produced different reactions from locals; on one hand, we observed that human visitors experienced some difficulty in understanding the purpose of the work, and in some cases, children thought the bird perches were gym toys. On the other hand, because the plots with seed banks looked like small gardens, they did not draw the attention of visitors.

For concrete-lined stretches of streams located in the urbanized regions of the study area, we conducted pre-intervention investigations of three approximately $20 \mathrm{~m}$ long stretches, each located on three different rivers, to establish hydrological and water quality characteristics and determine the most appropriate interventions to restore lost
Fig. 4. Map of the study area showing the areas suitable for passive restoration and unsuitable for passive restoration (requiring assisted restoration). The yellow point indicates the location where a connector can be constructed to link large forest fragments and improve the overall landscape connectivity. White patches depict forest fragments smaller than 50 ha. (For interpretation of the references to colour in this figure legend, the reader is referred to the web version of this article.) 
ecological functions. The investigated areas did not have any kind of vegetation (riparian, amphibian, or aquatic). Although for the three study areas the flow regimen was laminar (determined through Reynold's number), we noted differences in the slope, and therefore in flow velocity, among the stretches. In terms of water quality, there were differences in water turbidity and dissolved oxygen. At the time of writing, no fish species were discovered in the study sites. Since the stretches had different hydrological and water quality characteristics they did not receive the same interventions. However, the goals were similar in each case: improve river health; improve water quality, thereby improving the water quality of the receiving river (the Sorocaba River, which was the same for all streams, and is the biggest river in the region); and improve local scenic beauty through the implementation of landscaping related techniques and permit the reestablishment of local vegetation in order to plays a role as stepping stone for the landscape. Weeks after we execute the interventions, we observed distinct trajectories in each stretch, but as common features we observe the alteration in the velocity of the water flow and, by consequence, the formation of a sediment substrate and the resurgence of especially of the amphibian vegetation. The monitoring has been executed and will take place. Physical, chemical, and biological indicators have been compared with literature references of studies that were carried out in pristine streams on the Sorocaba (e.g., Smith et al., 2014).

Finally, for terrestrial locations where assisted restoration was necessary but the soil was degraded, a possible alternative was the use of mulching complemented with sowing. However, we believe that a single intervention that embraces these two actions might facilitate the achievement of conservation goals by simultaneously allowing the recuperation of soil degraded by erosion and controlling the invasion of exotic plant species. We found that practically all grass-covered sites (pasture lands) in the study area were covered with exotic, invasive Brachiaria spp. grass (principally Brachiaria decumbens). We also found that one factor limiting the germination and growth of this grass is light; therefore, we formulated and tested a new product that has the potential to control both erosion (by covering the soil surface with mulch) and the invasion of exotic, herbaceous plants (especially Brachiaria): a mix of seeds from eight plants species typically used in hydroseeding. The experiment was carried out on eight experimental rectangular plots ( $1 \mathrm{~m}$ wide, $5 \mathrm{~m}$ long, in a terrain of $50 \%$ slope) with the following features:

1. Two control plots, where the ground cover remained unchanged,

2. Two seed plots, where the ground cover was unchanged in the initial stages of the experiment and later received $25 \mathrm{~g} \mathrm{~m}^{2}$ (equivalent to $250 \mathrm{~kg} \mathrm{ha}$ ) of the mix of seeds, which were gently thrown manually over the ground surface,

3. Two mulch plots, where the ground was covered with a jute mesh tissue (mesh size $5.0 \mathrm{~mm}$ ). No seeds were thrown over these two plots.

4. Two mulch-seed plots, which did not receive any kind of soil treatment. Our product (called the bioblanket here) consisted of two layers of jute tissue (tissue of vegetal fiber) filled with a grass layer (harvested from the same location where the experiment was being carried out). The seeds used were from Avena strigosa, Vicia sativa, Cajanus cajan, Stylosanthes capitata, Crotalaria juncea, Dolichos lablab, Lolium multiflorum, and Raphanus sativus plants. This mix consists of species with different root systems (grasses and leguminous), different rates of germination and growth, and different resistance to drought, according to the technical information provided by the company selling the seed mix.

At least in Brazil, this product is usually sold separately, as two different products (mulching of vegetal fiber and hydroseeding), but here we are proposing the creation of a single, integrated, product that also uses the 'residual' material (grass) generated from the activity of clean the ground. This residual material (grass) is usually considered waste, but we are trying to convert it into a raw material that has some use value.

Furthermore, the product will have the potential to be used on terrain with different degrees of slope. Since water deficiency usually imposes major limitations on plant growth in hydroseeding projects (Oliveira et al., 2013), we believe that the organic layer formed by the fibrous dead-grass material between the two layers of jute tissue will be able to hold moisture and produce a micro-environment suitable for germination and growth of the saplings, until their roots reach the soil. We believe that the successful application of this product will also improve the physical and chemical features of the soil and provide suitable conditions for colonization by tree plant species, facilitating the process of passive ecological restoration and permitting the formation of small natural features that can serve as biodiversity hotspots or remnants (Poschlod and Braun-Reichert, 2017) with the potential to act as stepping stones.

\section{Discussion}

Landscape and regional approaches for restoration require effective ways of directing and prioritizing efforts that should also be cost-effective (Perring et al., 2015). This exact premise is fundamental for our framework; the GIS segment proposed in our model does not need specific software or applications to be used, and the SIR model used here to establish areas suitable for potential passive restoration (Bortoleto et al., 2016). Furthermore, although we carried out case studies demonstrating some specific techniques (nucleation, urban river restoration, and soil recovery), they were selected because they were the most adequate alternatives for our study area. Other techniques might be used in different areas according to their specific features.

The proposed techniques do not conflict with each other, but rather are complementary if and when deemed necessary. For example, a user could use perches integrated with the bioblanket technique to simultaneously control erosion and attract wildlife to bring seeds to degraded soil sited in a sloped region. Our model especially helps the user to locate potential areas to receive the best restoration alternatives.

Through our model, a user will be able to repair an ecosystem, reestablishing or continuing processes to allow it to become self-sustaining. All alternatives to assisted restoration suggested here are oneoff interventions (Hobbs and Cramer, 2008), meaning that after the initial use of the intervention (or set of simultaneous interventions), the system is left to its own.

The fact that we classify some fragments (the largest) as being of major concern for conservation and others as being of minor concern does not mean that the smaller fragments could or should be eliminated. In fact, smaller forest fragments always have some value for conservation and should also receive restorative actions, especially in their buffer zones (for instance, in riparian zone of non-concreted rivers), in order to enlarge them and improve the overall landscape connectivity. Our literature review found that there are 33 municipal parks in Sorocaba (Smith et al., 2014), but that only three of these parks are larger than 50 ha. In general, the parks are sited in regions with varying degrees of urbanization and show much evidence of degradation (including problems of bio-invasion); this is particularly true of the smaller parks. The parks cover a total area of $159.4 \mathrm{~km}^{2}$, corresponding to approximately $35 \%$ of the total area of the municipality, but not all are clearly depicted in the land cover map because of the resolution of the satellite image and the classification method. Despite this, it is evident that the study area has the potential to increase the percentage of areas suited for environmental conservation.

Due to the features of our model, and the fact that the GIS section was developed at the landscape level, the result of the application of the model will be a map of the study area showing areas suitable for passive restoration and for assisted restoration. We recognize, however, that the land use of all areas suitable for passive restoration cannot be 
completely altered to favor the restoration process.

Based on the results of the analyses generated by the model, landowners in the study area should be encouraged, directed, and assisted by technicians linked to regional decision makers in selecting potential areas on which to stop environmental degradation on their properties, thus favoring the passive restoration process. This will result in compliance with environmental legislation and at the same time favor the process of connecting existing forest fragments. Areas close to remaining fragments can aim to improve the buffer areas; those close to superficial water bodies, to re-vegetate the riparian area; those with boundaries near the urban property, to assess the potential of constructing natural fences. These are some examples of areas where degradation should be interrupted and natural restoration favored.

In contrast to sites with promising chances of recovery with minimal intervention or none, resources for technical interventions should ideally be allocated to sites where ecosystems are potentially resilient, but degradation or the landscape context inhibit natural recovery (Holl and Aide, 2011). In terms of river revitalization, while projects have already been carried out in some countries (Speed et al., 2016), in others such as Brazil, this idea is at an early stage. For instance, the 1st Brazilian Symposium for Urban Rivers Revitalization only took place in 2015. In this conference, several projects were presented that were being planned or carried out across some of the biggest Brazilian municipalities, but no project was complete.

\section{Conclusions}

The model proposed in this study allowed for the identification of areas where interventions of passive restoration have the potential to be successfully executed, following the generation of the local land cover map, and of other areas where technical or assisted actions are necessary to restore the ecosystem's resilience capacity and to drive its ecological succession trajectory. Using the graphical (flowchart) and textual description, a user is able to run the model for his or her case study.

Effective ecosystem restoration requires an extended view that includes historical, social, cultural, political, aesthetic, and moral aspects (Higgs, 1997; Whisenant, 1999). Our model clearly allows for the participation of members of society and permits the development of educational activities. By using our model, we identified some sitespecific restoration requirements, and our vision is that the alternatives of active interventions proposed must be always in conformity with the local ecological features and facilitate the autogenic recovery.

\section{Acknowledgements}

The authors thank Sao Paulo Research Foundation (FAPESP) for financially supporting the project (FAPESP grant number 2015/205606), the Municipal Secretary for Environment of Sorocaba for providing the three parks to conduct the experiment with nucleation techniques, and the Faculdade de Tecnologia de Sorocaba (FATEC) Campus Sorocaba for providing the terrain to conduct the experiment with the bioblanket.

\section{Appendix A. Supplementary data}

Supplementary data associated with this article can be found, in the online version, at http://dx.doi.org/10.1016/j.ecoleng.2017.07.024.

\section{References}

Aronson, J., Floret, C., Floch, E., Ovalle, C., Pontanier, R., 1993. Restoration and rehabilitation of degraded ecosystems in arid and semi-arid lands. I. A view from the south. Restor. Ecol. 1, 8-17.

Bechara, F.C., Dickens, S.J., Farrer, E.C., Larios, L., Spotswood, E.N., Mariotte, P., Suding, K.N., 2016. Neotropical rainforest restoration: comparing passive: plantation and nucleation approaches. Biodivers. Conserv. 25, 2021-2034.

Bergen, S.D., Bolton, S.M., Fridley, J.L., 2001. Design principles for ecological engineering. Ecol. Eng. 18, 201-210.

Beskow, S., Mello, C.R., Norton, L.D., Curi, N., Viola, M.R., Avanzi, J.C., 2009. Soil erosion prediction in the Grande River Basin: Brazil using distributed modeling. Catena 79, 49-59.

Boanares, D., de Azevedo, C.S., 2014. The use of nucleation techniques to restore the environment: a bibliometric analysis. Natureza Conservação 12, 93-98.

Bortoleto, L.A., Figueira, C.J.M., Dunning, J.B., Rodgers, J., Silva, A.M., 2016. Suitability index for restoration in landscapes: an alternative proposal for restoration projects. Ecol. Indic. 60, 724-735.

Chetkiewicz, C.L.B., St. Clair, C.C., Boyce, M.S., 2006. Corridors for conservation: integrating pattern and process. Annu. Rev. Ecol. Evol. Syst. 37, 317-342.

Higgs, E.S., 1997. What is good ecological restoration? Conserv. Biol. 11, 338-348.

Hill, J.L., Curran, P.J., 2003. Area: shape and isolation of tropical forest fragments: effects on tree species diversity and implications for conservation. J. Biogeogr. 30, 1391-1403.

Hilty, J.A., Lidicker Jr, W.Z., Merenlender, A., 2012. Corridor Ecology: The Science and Practice of Linking Landscapes for Biodiversity Conservation. Island Press.

Hobbs, R.J., Cramer, V.A., 2008. Restoration ecology: interventionist approaches for restoring and maintaining ecosystem function in the face of rapid environmental change. Annu. Rev. Environ. Resour. 33, 39-61.

Holl, K.D., Aide, T.M., 2011. When and where to actively restore ecosystems? For. Ecol. Manage. 261, 1558-1563.

IBGE (Brazilian Federal Institute for Geography and Statistics), 2016. Cid@ades - o Brasil município por município. Available online at www.ibge.gov.br (last Accessed in October 2016)

IGSP (Geological Institute of São Paulo State), 2009. Geological Map of Sorocaba Municipality (Report - in Portuguese). Scale: 1:50,000. 59 p.

Jackson, S.T., Hobbs, R.J., 2009. Ecological restoration in the light of ecological history. Science 325, 567-569.

Jax, K., 2005. Function and functioning in ecology: what does it mean? Oikos 111, 641-648.

Kronka, F.J.N., et al., 2005. Inventário Florestal da Vegetação Natural do Estado de São Paulo. Imprensa Oficial, São Paulo: Secretaria do Meio Ambiente/ Instituto Florestal $200 \mathrm{p}$.

Land- Use and Land-Cover Change: Local Processes and Global Impacts. In: Lambin, E.F., Geist, H.J. (Eds.), Springer Science \& Business Media.

Lillesand, T., Kiefer, R.W., Chipman, J., 2014. Remote Sensing and Image Interpretation. John Wiley \& Sons.

Liu, S., Deng, L., Dong, S., Zhao, Q., Yang, J., Wang, C., 2014. Landscape connectivity dynamics based on network analysis in the Xishuangbanna Nature Reserve. China. Acta Oecol. 55, 66-77.

Marcot, B.G., Vander Heyden, M., 2001. Key ecological functions of wildlife species. Communities 1 (3), 14-41.

McGill, B.J., Dornelas, M., Gotelli, N.J., Magurran, A.E., 2015. Fifteen forms of biodiversity trend in the Anthropocene. Trends Ecol. Evol. 30, 104-113.

Murcia, C., Guariguata, M.R., Andrade, A., Andrade, G.I., Aronson, J., Escobar, E.M., et al., 2015. Challenges and prospects for scaling up ecological restoration to meet international commitments: colombia as a case study. Conserv. Lett. 9, 213-220.

O'Neill, M.P., Schmidt, J.C., Dobrowolski, J.P., Hawkins, C.P., Neale, C.M., 1997. Identifying sites for riparian wetland restoration: application of a model to the upper Arkansas River Basin. Restor. Ecol. 5, 85-102.

Oliveira, J.B., Camargo, M.N., Rossi, M., Calderano Filho, B., 1999. Mapa Pedológico do Estado de São Paulo Legenda Expandida. Instituto Agronômico, EMBRAPA-Solos, Campinas, Rio de Janeiro 64 p.

Oliveira, G., Clemente, A., Nunes, A., Correia, O., 2013. Limitations to recruitment of native species in hydroseeding mixtures. Ecol. Eng. 57, 18-26.

Patel, D.P., Srivastava, P.K., Gupta, M., Nandhakumar, N., 2015. Decision Support System integrated with Geographic Information System to target restoration actions in watersheds of arid environment: a case study of Hathmati watershed, Sabarkantha district, Gujarat. J. Earth Syst. Sci. 124, 71-86.

Paul, M.J., Meyer, J.L., 2001. Streams in the urban landscape. Annu. Rev. Ecol. Syst. 32, 333-365.

Perring, M.P., Standish, R.J., Price, J.N., Craig, M.D., Erickson, T.E., Ruthrof, K.X., et al., 2015. Advances in restoration ecology: rising to the challenges of the coming decades. Ecosphere 6, 1-25.

Piniewski, M., Gottschalk, L., Krasovskaia, I., Chormański, J., 2012. A GIS-based model for testing effects of restoration measures in wetlands: a case study in the Kampinos National Park, Poland. Ecol. Eng. 44, 25-35.

Poschlod, P., Braun-Reichert, R., 2017. Small natural features with large ecological roles in ancient agricultural landscapes of Central Europe-history, value, status, and conservation. Biol. Conserv. 211, 60-68.

Prach, K., Hobbs, R.J., 2008. Spontaneous succession versus technical reclamation in the restoration of disturbed sites. Restor. Ecol. 16, 363-366.

Schulze, E.D., Mooney, H.A. (Eds.), 2012. Biodiversity and Ecosystem Function. Springer Science \& Business Media.

Silva, A.M., Braga Alves, C., Alves, S.H., 2010. Roadside vegetation: estimation and potential for carbon sequestration. iForest-Biogeosci. For. 3, 124.

Silveira, F.M., Silva, A.M., Ikematsu, P., Bomback, M., Paula, F.P., Nogueira, D.P., Alves, S.H., 2009. Variation of the occupied area by riparian zone according to considered width. Caminhos de Geografia 10, 111-119.

Smith, W.S., Ribeiro, C.A. (organizers), Parque Natural Municipal Corredores de Biodiversidade: pesquisas e perspectivas futuras, 2015, Municipal Secretary of Sorocaba, SP, Brazil, 230 p.

Smith, W.S., Mota Jr., V.D., Carvalho, J.L. (organizers), Biodiversidade do Município de Sorocaba, 2014, Municipal Secretary of Sorocaba, SP, Brazil, 269 p.

Speed, R., Tickner, D., Naiman, R., Gang, L., Sayers, P., Yu, W., et al., 2016. River 
Restoration: A Strategic Approach to Planning and Management. UNESCO Publishing.

Suding, K.N., Hobbs, R.J., 2009. Threshold models in restoration and conservation: a developing framework. Trends Ecol. Evol. 24, 271-279.

Tilman, D., Clark, M., Williams, D.R., Kimmel, K., Polasky, S., Packer, C., 2017. Future threats to biodiversity and pathways to their prevention. Nature 546, 73-81.

Traveset, A., Heleno, R., Nogales, M., 2013. The ecology of seed dispersal: seeds. Ecol. Regen. Plant Commun. 3, 62-93.

USDT - United States Department of Transportation, 2011. Wildlife Crossing Structure Handbook - Design and Evaluation in North America. Central Federal Lands Highway Division, USDT, Lakewood, CO, USA 223 p.
Vettorazzi, C.A., Valente, R.A., 2016. Priority areas for forest restoration aiming at the conservation of water resources. Ecol. Eng. 94, 255-267.

Walker, L.R., Walker, J., Hobbs, R.J., 2007. Linking Restoration and Ecological Succession (No. Sirsi i9780387353029). Springer, London.

Whisenant, S.G., 1999. Repairing Damaged Wildlands: a Process-oriented, LandscapeScale Approach. Cambridge University Press.

Wohl, E.E., Angermeier, P.L., Bledsoe, B., et al., 2005. River restoration. Water Resour. Res. 41, 12.

Yin, Y., Zhang, X., Lin, D., Yu, H., Shi, P., 2014. GEPIC-VR model: a GIS-based tool for regional crop drought risk assessment. Agric. Water Manage. 144, 107-119. 